\title{
Expression Pattern Analysis of Four Mlo Genes from Rose
}

\author{
Xianqin Qiu \\ Flower Research Institute, National Engineering Research Center for Ornamental Horticulture, \\ Yunnan Flower Breeding Key Lab, Yunnan Academy of Agricultural Sciences, Kunming 650200, \\ China; and Key Laboratory of Horticultural Plant Biology, Ministry of Education, College of \\ Horticulture and Forestry Sciences, Huazhong Agricultural University, Wuhan 430070, China
}

\author{
Hongying Jian, Qigang Wang, and Kaixue Tang ${ }^{1}$ \\ Flower Research Institute, National Engineering Research Center for Ornamental Horticulture, \\ Yunnan Flower Breeding Key Lab, Yunnan Academy of Agricultural Sciences, Kunming 650200, \\ China
}

\begin{abstract}
Manzhu Bao ${ }^{1}$
Key Laboratory of Horticultural Plant Biology, Ministry of Education, College of Horticulture and Forestry Sciences, Huazhong Agricultural University, Wuhan 430070, China

AdDitional Index words. Rosa, mildew resistance locus o, Podosphaera pannosa, real-time quantitative PCR, powdery mildew

Abstract. Rose (Rosa hybrida) is one of the most economically important ornamentals worldwide. Powdery mildew (Podosphaera pannosa) is a major disease in cut and potted roses. In dicots such as arabidopsis (Arabidopsis thaliana), pea (Pisum sativum), and tomato (Solanum lycopersicum), loss-of-function mutations in mildew resistance locus o (Mlo) genes confer high levels of broad-spectrum resistance to powdery mildew. Here, we present spatiotemporal expression patterns of four Mlo genes from $R$. hybrida based on real-time fluorescence quantitative polymerase chain reaction (qPCR). Phylogenetically closely related $R$. hybrida mildew resistance locus o $(R h M L O)$ genes showed similar or overlapping tissue specificity and analogous responsiveness to external stimuli. RhMLO1 and $R h M L O 2$ transcriptional levels were upregulated more than 2 -fold by external stimuli, especially by inoculation with powdery mildew fungus $P$. pannosa at early time points. This phenomenon was not found for $R h M L O 3$ or $R h M L O 4$. The results indicated that RhMLO1 and $\mathrm{RhMLO2}$ might play important roles in rose-powdery mildew pathogen interactions. Our findings may provide useful information for the study of mechanisms of powdery mildew susceptibility in rose.
\end{abstract}

Powdery mildew is one of the most serious rose diseases. Nearly $40 \%$ of the fungicide sprayed on cut and potted roses is intended to control powdery mildew (Linde and Shishkoff, 2003). It can cause distortion and death of leaves and shoots, but even a mild case makes plants unsightly (Linde and Shishkoff, 2003). Disease control is economically important for cut and potted roses, which are almost exclusively produced in greenhouses throughout temperate regions or at higher elevations in the tropics. Powdery mildew in roses is caused by the obligate biotrophic ascomycete Podosphaera pannosa [formerly Sphaerotheca pannosa (Linde and Shishkoff, 2003)]. P. pannosa belongs to the family Erysiphaceae, which consists of other important powdery mildews such as Blumeria graminis of cereals (Gramineae). The pathogen species show considerable

Received for publication 26 Jan. 2015. Accepted for publication 20 May 2015. This study was supported by funds from Ministry of Science and Technology Project of China (no. 2011AA100208), National Natural Science Foundation of China (no. 31160403), Natural Science Foundation of Yunnan (nos. 2011FB124, 2014FB158, and 2011BB013), and the Ministry of Agriculture Project of China (nos. 200903020 and 2011G17).

We gratefully acknowledge reviewers for their valuable suggestions on our manuscript. We thank Thomas Debener and Helgard Kaufmann of Hannover University in Germany for their comments and valuable suggestions on our manuscript.

${ }^{1}$ Corresponding author. E-mail: kxtang@hotmail.com or mzbao@mail.hzau. edu.cn. variation in pathogenicity (Leus et al., 2006; Linde and Debener, 2003).

Some strategies to develop powdery mildew-resistant crops have relied on the gene-for-gene resistance approach, which depends on the identification of a resistance gene in the host specific to a corresponding avirulence gene in the pathogen (Flor, 1971). Another strategy is based on a loss-of-function mutation in the mildew resistance locus o-based (Mlo) gene. Mlo resistance was characterized several decades ago in barley (Hordeum vulgare) as a recessively inherited trait that is effective against all known races of barley powdery mildew [B. graminis f.sp. hordei (Jorgensen, 1992)]. The MLO protein belongs to a plant-specific family of membrane proteins that contains seven transmembrane helices and a C-terminal calmodulin-binding domain (CaMBD) (Devoto et al., 1999; Kim et al., 2002). In dicots such as arabidopsis, pea, tomato, and peach (Prunus persica), loss-of-function mutations in Mlo genes confer high levels of broad-spectrum resistance (Bai et al., 2008; Consonni et al., 2006; Humphry et al., 2011; Jiwan et al., 2013; Pavan et al., 2011). Therefore, Mlo genes provide a general route by which to achieve highly effective race-independent resistance in angiosperms.

So far, four Mlo homologs RhMLO1-RhMLO4 were isolated from rose leaves (Kaufmann et al., 2012). Phylogenetic analysis showed that all Mlo genes from dicots for which a function in powdery mildew-host interaction has been experimentally 
demonstrated fall into one phylogenetic clade. The clade consists of two smaller clades, one consists of rose genes RhMLO3 and 4, and the arabidopsis genes AtMLO2, 6, and 12; the other consists of rose genes $R h M L O 1$ and 2, and pea gene PsMLO2 (Kaufmann et al., 2012). All four rose genes fall into the dicot cluster for powdery mildew-related Mlos and are therefore candidate Mlo orthologs. Gene expression analysis has become increasingly important in many fields of biological research. Understanding patterns of expressed genes is expected to provide insight into complex regulatory networks and will most likely lead to the identification of genes relevant to new biological processes or that are implicated in disease (Vandesompele et al., 2002). Real-time quantitative PCR (RT-qPCR) has become the gold standard for the quantitative analysis of nucleic acids because of its high sensitivity, adequate reproducibility, broad quantification range, and ease of use. RT-qPCR is the most prominent gene expression quantification technique to date (Derveaux et al., 2010).

Here, the aim of our study was to obtain better insight into the characteristics of Mlo family members in rose by RT-qPCR. Phylogenetically closely related $R h M L O$ genes showed similar or overlapping tissue specificity and analogous responsiveness to external stimuli. Our findings will help us to understand the role of the four $R h M L O$ genes in response to biotic and abiotic stresses.

\section{Materials and Methods}

Plant materials and treatment. The four Mlo genes [RhMLO1-RhMLO4 (GenBank accession nos. JX847131JX847134)] were isolated from Rosa multiflora hybrids, and R. hybrida 'Fentuan' (Tang, 2009) possesses these genes based on our preliminary work. Therefore, R. hybrida 'Fentuan' was employed as the plant material for gene expression pattern analysis. Three clones of 'Fentuan' ( 2 years after cutting propagation) were cultivated in a greenhouse under a 16-h light/8-h dark cycle, with a constant temperature of $22^{\circ} \mathrm{C}$. Roots were induced on stem cuttings in hydro-culture according to Mutui et al. (2005). Calli were induced according to Ding (2012). Tender leaves (folded leaves), adult leaves (the third to fifth unfolded leaves from the shoot apex), old leaves (the last unfolded leaves from the shoot apex), stems (nonlignification), buds (0.5 cm diameter), petals (from blooming flowers), flowers (blooming flowers), roots (taproots and lateral roots), and calli (1-month old) were collected from the three separate clones.

Several stress treatments were conducted on the third to fifth unfolded leaves from the shoot apex. The leaflets were placed in plastic boxes on water-saturated tissue paper. Here, some leaflets were collected before being treated or inoculated as controls. For wounding, the leaves were cut with a scalpel and stored for $2 \mathrm{~h}$ at $20^{\circ} \mathrm{C}$. Heat stress and cold stress were applied by placing the wet plastic boxes at $42{ }^{\circ} \mathrm{C}$ for $1 \mathrm{~h}$ and at $4{ }^{\circ} \mathrm{C}$ for $12 \mathrm{~h}$, respectively. Two monospore isolates of $P$. pannosa, isolate MC and isolate YF, both from Kunming, China (Qiu et al., 2015), were maintained in vitro as described by Linde and Debener (2003). Pathogen stress was induced by the inoculation of leaflets with the two mixed compatible isolates at a density of $10^{4}$ conidia/mL and incubated for $6,12,24,36$, 48, 72, and $96 \mathrm{~h}$ at $20^{\circ} \mathrm{C}$ as described by Yan et al. (2006).

Three replicates were collected for each tissue and each treatment. All samples were immediately frozen in liquid nitrogen after harvest and stored at $-80{ }^{\circ} \mathrm{C}$ for less than 1 month before RNA extraction.

Total RNA EXtraction AND CDNA sYNThesis. Total RNA was extracted from 30 to $50 \mathrm{mg}$ of each sample using TransZol Plant (TransGen Biotech, Beijing, China) according to the manufacturer's instructions. The remaining DNA was removed by DNase treatment using a DNA-free Kit (Invitrogen, Shanghai, China). The RNA concentration was assessed spectrophotometrically at $260 \mathrm{~nm}$ and was checked for purity by determining the optical density (OD) 260/280 nm and the OD 260/230 nm ratios. The RNA quality was assessed by gel electrophoresis and for a subset of samples with a Bioanalyzer 2100 using the RNA 6000 Nano Laboratory-Chip Kit (Agilent Technologies, Basel, Switzerland). For each sample, $500 \mathrm{ng}$ of total RNA was reverse-transcribed using the iScript cDNA Synthesis Kit (BioRad, Hercules, CA).

Selection of Reference genes AND PCR PRimer Design. Based on work by Klie and Debener (2011), two reference genes, protein phosphatase $2 \mathrm{~A}(P P 2 A)$ and ubiquitin-conjugating protein $(U B C)$, were selected for the expression analysis of different tissues, and SAND-family protein $(S A N D)$ and $U B C$ were selected for the analysis of stressed leaves (Table 1). Four $R h M L O$ genes were analyzed for secondary structures by the

Table 1. Primer sequences, product length, and reaction efficiency of Rosa hybrida mildew resistance locus o-1-4 (RhMLO1-RhMLO4) and three reference genes in real-time quantitative PCR.

\begin{tabular}{|c|c|c|c|c|}
\hline Gene & $\begin{array}{c}\text { GenBank } \\
\text { accession no. }\end{array}$ & Primer sequence $\left(5^{\prime}-3^{\prime}\right)$ & $\begin{array}{l}\text { Amplicon length } \\
\text { (nucleotides) }\end{array}$ & $\begin{array}{l}\text { Efficiency } \\
(\%)\end{array}$ \\
\hline \multirow{2}{*}{$\begin{array}{l}\text { RhMLOI (Rosa hybrida mildew } \\
\quad \text { resistance locus o-1) }\end{array}$} & \multirow[t]{2}{*}{ JX847131 } & F:TTAGGAAGAGCCAAGATGAGA & \multirow[t]{2}{*}{225} & \multirow[t]{2}{*}{101.5} \\
\hline & & R:CCGCAAGGTCAAGTAATCAAC & & \\
\hline \multirow{2}{*}{$\begin{array}{l}\text { RhMLO2 ( } R \text {. hybrida mildew } \\
\quad \text { resistance locus o- } 2 \text { ) }\end{array}$} & \multirow[t]{2}{*}{ JX847132 } & F:TCTTTGCGTGGACTTGGTATG & \multirow[t]{2}{*}{256} & \multirow[t]{2}{*}{109.8} \\
\hline & & R:GGAACTGAATGCTTGCTCTG & & \\
\hline \multirow{2}{*}{$\begin{array}{l}\text { RhMLO3 (R. hybrida mildew } \\
\quad \text { resistance locus o- } 3 \text { ) }\end{array}$} & \multirow[t]{2}{*}{ JX847133 } & F:ATGGAACTTGAATATGAGCG & \multirow[t]{2}{*}{235} & \multirow[t]{2}{*}{108.6} \\
\hline & & R:CGATTGGATCTTGTAGAACTG & & \\
\hline \multirow{2}{*}{$\begin{array}{l}\text { RhMLO4 (R. hybrida mildew } \\
\text { resistance locus o- } 4 \text { ) }\end{array}$} & \multirow[t]{2}{*}{ JX847134 } & F:GACCCTCAATGTAAAAAACATGA & \multirow[t]{2}{*}{222} & \multirow[t]{2}{*}{90.9} \\
\hline & & R:TAGGAGCAAGGACAGGAATC & & \\
\hline \multirow[t]{2}{*}{$P P 2 A$ (protein phosphatase $2 \mathrm{~A}$ ) } & \multirow[t]{2}{*}{ JN399224 } & F:TGTCACTGCATCAAAGGACAG & \multirow[t]{2}{*}{110} & \multirow[t]{2}{*}{101.8} \\
\hline & & R:GACGAATTGTCTTCTCCACCA & & \\
\hline \multirow[t]{2}{*}{ SAND (SAND-family protein) } & \multirow[t]{2}{*}{ JN399228 } & F:GTGTTGAGGAGTTGCCTCTTG & \multirow[t]{2}{*}{97} & \multirow[t]{2}{*}{101.7} \\
\hline & & R:AACCTGTCGGGAGAATCTGTT & & \\
\hline \multirow{2}{*}{$\begin{array}{l}U B C \text { (ubiquitin-conjugating } \\
\text { protein) }\end{array}$} & \multirow[t]{2}{*}{ JN399227 } & F:GCCAGAGATTGCCCATATGTA & \multirow[t]{2}{*}{109} & \multirow[t]{2}{*}{108.4} \\
\hline & & R:TCACAGAGTCCTAGCAGCACA & & \\
\hline
\end{tabular}


UNAFold (version 3.4; RNA Institute, Albany, NY) software (Bustin et al., 2009). Because each rose Mlo gene has more than one allele (Kaufmann et al., 2012), the primers for each Mlo gene were designed to match only one allele (their sequences are the same as GenBank no. JX847131-JX847134) using Beacon Designer (version 8.0; Premier Biosoft International, Palo Alto, CA) software with the following specifications: optimal annealing temperature at $58 \pm 2{ }^{\circ} \mathrm{C}$, optimal primer length of 18-24 nucleotides, optimal amplicon length of 80 $300 \mathrm{bp}$, content of guanine and cytosine between $45 \%$ and $55 \%$. OligoAnalyzer (version 1.0.2; Integrated DNA Technologies, Coralville, IA) was used to control for dimer and hairpin formation. The primers were highly specific for one allele of each gene as confirmed by a Blast online search (National Center for Biotechnology Information, 2014). The performance of the primers was tested in PCR reactions with both genomic DNA and complementary DNA (cDNA) as substrates. The sequencing results of PCR products showed a $100 \%$ match to the specific range of sequences in the GenBank accession for each rose $M l o$ gene.

RT-QPCR AND DATA ANALYSES. The amplification reactions were performed in transparent 0.1-mL, 96-well plates (Bio-Rad) using EvaGreen detection chemistry and run on the CFX96 system (Bio-Rad). The reactions were prepared in a total volume of $20 \mu \mathrm{L}$ containing $2 \mu \mathrm{L}$ of template, $1 \mu \mathrm{L}$ of each primer [0.25 nM], $10 \mu \mathrm{L}$ of SsoFast EvaGreen Supermix (Bio-Rad), and $6 \mu \mathrm{L}$ of nuclease-free water. The water-only controls included $2 \mu \mathrm{L}$ of nuclease-free water instead of a cDNA template and were run for each primer pair on each plate. The cycling conditions were set as follows: initial denaturation for $5 \mathrm{~min}$ at $95^{\circ} \mathrm{C}$, followed by 35 cycles of $10 \mathrm{~s}$ at $95^{\circ} \mathrm{C}, 30 \mathrm{~s}$ at $58^{\circ} \mathrm{C}$, and $30 \mathrm{~s}$ at $72{ }^{\circ} \mathrm{C}$, + Plate Read. The efficiency of each primer pair was analyzed with five serial 5-fold dilutions of cDNA of leaves and calculated from the slope of the regression line of the quantification cycle $(\mathrm{Cq})$ vs. the relative concentration of cDNA (Pfaffl, 2001). The amplification specificity for each primer pair was tested by a melting curve analysis ranging from 65 to $95{ }^{\circ} \mathrm{C}$ with temperature steps of $0.5{ }^{\circ} \mathrm{C}$ [CFX Manager $^{\mathrm{TM}}$ Software Help Introduction (Bio-Rad)]. Two replicate amplifications were done for each cDNA.

The data were analyzed by CFX Manager Software (Bio-Rad). When a control sample (control) was assigned, the relative quantity (RQ) for any sample of a gene of interest (GOI) was calculated with the following formula according to Hellemans et al. (2007): Efficiency $(\mathrm{E})=(\%$ Efficiency $\times 0.01)+1 ; \mathrm{RQ}_{\text {sample }(\mathrm{GOI})}=$ $E_{\mathrm{GO}}^{\left(C \mathrm{q}_{\text {control }}-C \mathrm{q}_{\text {sample }}\right)} . C \mathrm{q}_{\mathrm{control}}=$ average $C \mathrm{q}$ for the control sample; $C \mathrm{q}_{\text {sample }}=$ average $C \mathrm{q}$ for any samples with a GOI.

Normalized expression (NE) is the relative quantity of the target gene normalized to the quantities of more than one reference gene. Reference target (ref) in a run that includes one or more reference targets in each sample. The calculation for NE was described in the following formula according to Vandesompele et al. (2002) and Hellemans et al. (2007), and it uses the RQ calculation:

$$
\begin{aligned}
& \mathrm{NE}_{\text {sample }(\mathrm{GOI})}= \\
& \frac{\mathrm{RQ}_{\text {sample }(\mathrm{GOI})}}{\left(\mathrm{RQ}_{\text {sample }(\mathrm{ref} 1)} \times \mathrm{RQ}_{\text {sample }(\mathrm{ref} 2)} \times \ldots \times \mathrm{RQ}_{\text {sample }(\mathrm{refn})}\right)^{\frac{1}{n}}} .
\end{aligned}
$$

Statistical analysis of variance (ANOVA) was performed using SAS (version 9.0; SAS Institute, Cary, NC) software.
Standard errors of the mean was calculated and represented as in Figs. 1 and 2 and Table 2 (Joseph et al., 2010).

\section{Results}

Primer SPeCificity and EFficiency of RT-QPCR. The amplification specificity for each primer pair was tested by a melting curve (Supplemental Fig. 1). Each primer pair yielded a single-peak melt curve without nonspecific products, which indicated that the specificity was very high and the credibility of the RT-qPCR products was also very high.

PCR amplification efficiency was established by a standard curve (Supplemental Fig. 2). The mean primer efficiency varied from $90.9 \%$ for $R h M L O 4$ to $109.8 \%$ for $R h M L O 2$ (Table 1), which was in the range of the effective amplification efficiency scope of $90 \%$ to $110 \%$ [CFX Manager Software Protocols (Bio-Rad)].

EXPRESSION PATTERNS IN DIFFERENT TISSUES. For the determination of $R h M L O$ expression in different tissues, we used the reference genes $P P 2 A$ and $U B C$ as internal controls. Expression levels in different tissues were calculated relative to the expression levels in root samples. The expression levels of the four $R h M L O$ genes in nine different tissues are shown in Fig. 1.

None of the four genes are highly expressed in roots, stems, or calli, and all of the genes have the highest expression in leaves (with expression in younger leaves being higher than in older leaves). $R h M L O 1$ to $R h M L O 3$ are also, to varying degrees, expressed at intermediate levels in other tissues, whereas RhMLO4 is expressed at very high levels in leaves but at very low levels in all other tissues.

EXPRESSION PATTERN IN STRESSED LEAVES. To analyze stressed leaves, we used the two reference genes $S A N D$ and $U B C$ as internal controls. Expression levels in stressed leaves were calculated relative to the expression level in untreated leaves. The expression levels of the four $R h M L O$ genes in leaves that underwent different abiotic and biotic stresses are shown in Table 2 and Fig. 2. Both RhMLO1 and RhMLO2 exhibited similar expression patterns in stressed leaves: their expression levels increased more than 2-fold on treatment with different abiotic stimuli. Furthermore, these transcripts were also upregulated more than 2-fold at time points of $6,12,24,36$, and $48 \mathrm{~h}$ postinoculation (HPI) with $P$. pannosa.

Compared with RhMLO1 and RhMLO2, both RhMLO3 and RhMLO4 showed opposite expression patterns after biotic or abiotic stress. Their expression levels decreased more than 2-fold on treatment with abiotic stimuli, and they were downregulated upon inoculation with $P$. pannosa.

\section{Discussion}

Gene expression pattern research is crucial for the elucidation of gene function in modern molecular biology. The spatiotemporal expression pattern of a certain gene is closely related to its function, so identifying the expression pattern of a gene may be an important step in explaining its function and the underlying mechanism. Mlo genes have been isolated from several species based on their similarity to well-characterized genes from barley and arabidopsis. However, only a few of these sequences have been functionally characterized and shown to be involved in plant-powdery mildew interactions by further experiments (Cheng et al., 2012; Feechan et al., 2008; Jiwan et al., 2013; Liu and Zhu, 2008; Yu et al., 2005; 

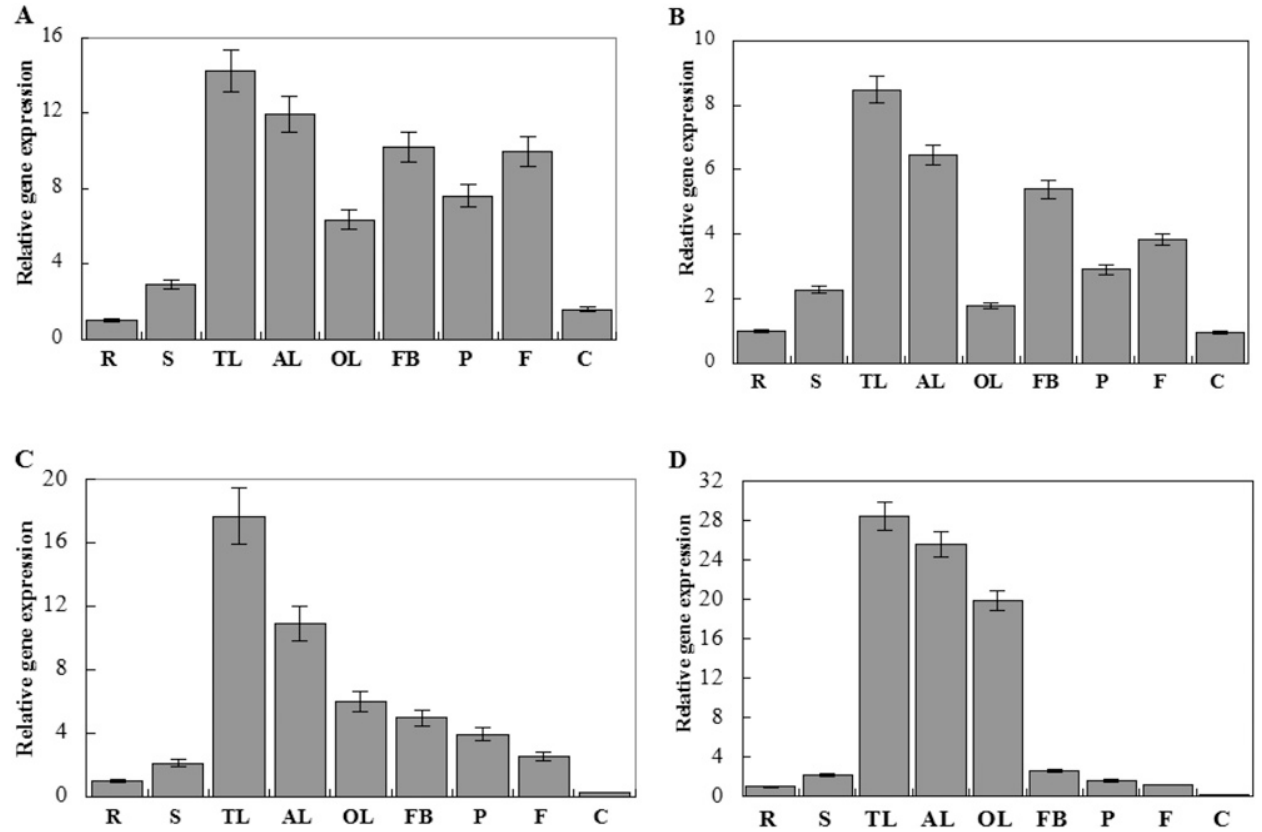

Fig. 1. Relative expression levels of Rosa hybrida mildew resistance locus o-1-4 [RhMLO1-RhMLO4 (A-D)] in nine tissues of $R$. hybrida 'Fentuan' based on real-time quantitative PCR. Two reference genes, protein phosphatase 2A $(P P 2 A)$ and ubiquitin-conjugating protein $(U B C)$, were internal control genes. The expression level in roots was used as a baseline (1.00) for calculating relative expression levels in other tissues. Data are shown as the means $\pm \mathrm{SE} . \mathrm{R}=$ roots; $\mathrm{S}=$ stems; $\mathrm{TL}=$ tender leaves; $\mathrm{AL}=$ adult leaves; $\mathrm{OL}=$ old leaves; $\mathrm{FB}=$ flower buds; $\mathrm{P}=$ petals; $\mathrm{F}=$ flowers; $\mathrm{C}=$ calli.
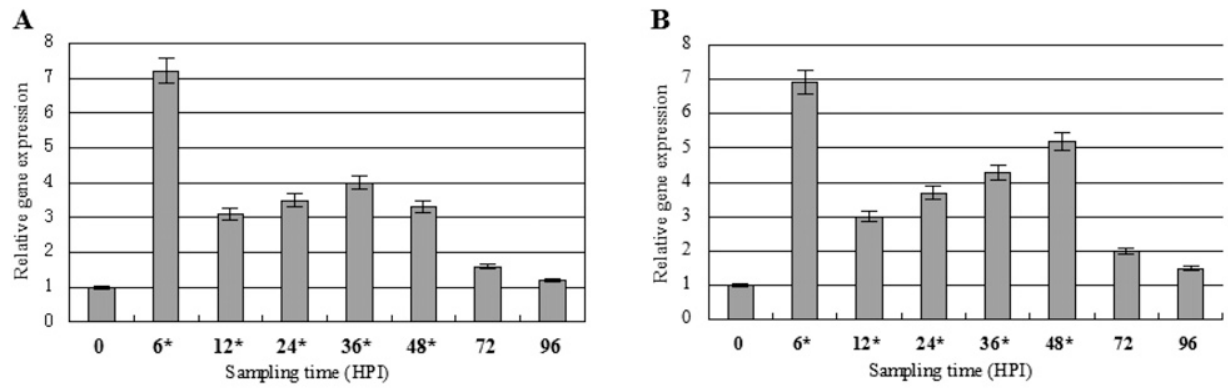

C
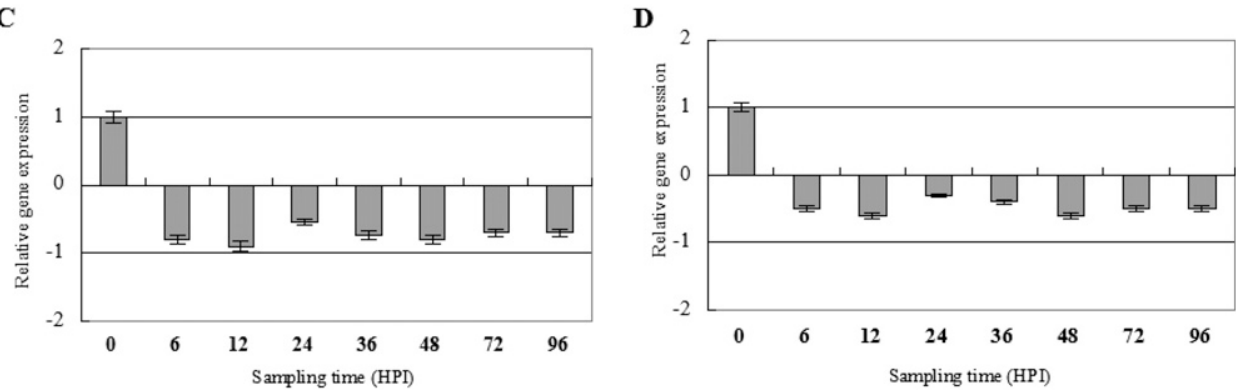

Fig. 2. Relative expression levels of Rosa hybrida mildew resistance locus o-1-4 [RhMLO1-RhMLO4 (A-D)] in leaves of $R$. hybrida 'Fentuan' inoculated with Podosphaera pannosa $(P p)$ based on real-time quantitative PCR. Leaves were sampled at $6,12,24,36,48,72$, and 96 h post-inoculation (HPI). Two reference genes, SAND-family protein $(S A N D)$ and ubiquitin-conjugating protein $(U B C)$, were used as internal control genes. The expression level of uninoculated leaves ( $0 \mathrm{HPI})$ was used as the baseline (1.00) for calculating relative expression levels in leaves inoculated with $P p$ at different stages. Data are shown as the means \pm SE. Significant differences compared with untreated leaves $(0 \mathrm{HPI})$ via analysis of variance (ANOVA) at $P \leq 0.05$ are indicated with an asterisk.

Zheng et al., 2013). These members are characterized by the presence of a tetrapeptide (D/E-F-S-T/F) motif in the cytoplasmic region at the C-terminus of the protein and their responses to powdery mildew infection at early time points (Bai et al.,
2008; Chen et al., 2006; Piffanelli et al., 2002; Zheng et al., 2013).

Phylogenetic analysis showed that RhMLO1 and RhMLO2 contain all of the sequence signatures considered to be diagnostic for MLOs. However, all sequence motifs were conserved, except that one mutation at the C-terminus in RhMLO3 and RhMLO4 altered the amino acids [S-F-S-F instead of D/E-F-S-T/F (Kaufmann et al., 2012)]. Therefore, to better understand the functional characteristics of these four genes, an analysis of their spatiotemporal expression patterns is necessary. Here, we presented the expression patterns of $R h M L O$ genes both in different tissues and after several biotic and abiotic stress stimuli of R. hybrida 'Fentuan'.

The molecular phylogenetic tree containing Mlo genes of other species was constructed by Kaufmann et al. (2012). RhMLOl and RhMLO2 clustered together with the $M L O 1$ gene from $P$. sativum, while $\mathrm{RhMLO} 3$ and $\mathrm{RhMLO} 4$ were in a separate cluster with arabidopsis $M L O 2, M L O 6$, and $M L O 12$. The transcriptional levels of phylogenetically closely related $R h M L O$ genes showed similar or overlapping tissue specificity and analogous responsiveness to external stimuli. RhMLO1 and RhMLO2 transcript levels were higher in young leaves and floral buds than in other tissues. The expression levels in those tissues may have a connection to susceptibility because of the susceptibility of those tissues (Tang, 2009). Piffanelli et al. (2002) found that the expression of Mlo genes from barley was upregulated by fungal infection and wounding. Chen et al. (2006) reported that the transcripts of AtMLO2, AtMLO6, and AtMLO12 genes from arabidopsis were upregulated more than 2-fold by chemical, fungal, bacterial, and abiotic stresses. Bai et al. (2008) found that the transcript of SIMLO1 from tomato was upregulated at time points of 6 and 36 HPI with tomato powdery mildew (Oidium neolycopersici). Shen et al. (2012) reported that the expression of Mlo from soybean (Glycine max) was influenced by various phytohormone and abiotic treatments. Zheng et al. (2013) reported that the transcripts of CaMLO2 from pepper (Capsicum annuum) were upregulated at time points of 5, 7, and 25 HPI with pepper powdery 
Table 2. Relative expression levels of Rosa hybrida mildew resistance locus o-1-4 (RhMLO1-RhMLO4) in different stressed leaves of R. hybrida 'Fentuan' based on real-time quantitative PCR. ${ }^{\mathrm{z}}$

\begin{tabular}{|c|c|c|c|c|}
\hline \multirow[b]{2}{*}{ Treatments (in leaves) ${ }^{\mathrm{y}}$} & \multicolumn{4}{|c|}{ Relative gene expression $(\text { mean } \pm \mathrm{SE})^{\mathrm{x}}$} \\
\hline & $R h M L O 1$ & RhMLO2 & RhMLO3 & RhMLO4 \\
\hline Wounded (2 h) & $\mathbf{3 . 1 0} \pm 0.14^{*}$ & $\mathbf{3 . 0 3} \pm 0.13^{*}$ & $-2.74 \pm 0.14^{*}$ & $-5.90 \pm 0.24^{*}$ \\
\hline Heated $(1 \mathrm{~h})$ & $\mathbf{3 . 0 7} \pm 0.17^{*}$ & $\mathbf{3 . 0 5} \pm 0.11^{*}$ & $-3.33 \pm 0.19^{*}$ & $-3.81 \pm 0.20^{*}$ \\
\hline Cold (12 h) & $3.21 \pm 0.12^{*}$ & $3.32 \pm 0.11^{*}$ & $-3.59 \pm 0.21 *$ & $-4.11 \pm 0.17^{*}$ \\
\hline
\end{tabular}

${ }^{\mathrm{z}}$ Two reference genes, SAND-family protein $(S A N D)$ and ubiquitin-conjugating protein $(U B C)$, were internal control genes. The expression level in untreated leaves was used as a baseline (1.00) for calculating relative expression levels in different stressed leaves. Significant differences compared with untreated leaves are indicated with an asterisk $(P \leq 0.05)$.

${ }^{y}$ For wounding, the leaves were induced with a scalpel and stored for $2 \mathrm{~h}$ at $20^{\circ} \mathrm{C}$. Heat stress and cold stress were applied at $42{ }^{\circ} \mathrm{C}$ for $1 \mathrm{~h}$ and at $4{ }^{\circ} \mathrm{C}$ for $12 \mathrm{~h}$, respectively.

${ }^{x}$ Positive numbers in bold show they are upregulated in expression levels; negative numbers show they are down-regulated in expression levels.

mildew (Leveillula taurica). The abovementioned all candidate genes have been shown to be involved in resistance or susceptibility via complementation or gene knockout. As shown for candidate genes from other species, we found that transcript levels of RhMLO1 and RhMLO2 were significantly affected by biotic and abiotic stresses, especially by inoculation with $P$. pannosa at early time points $(6-48 \mathrm{~h})$. Taken together, our results indicate that RhMLO1 and RhMLO2 had similar expression patterns and were upregulated analogously by a variety of stimuli in our study.

Originally, RhMLO3 and $R h M L O 4$ were thought to be functional candidate $M l o$ orthologs in rose based on phylogenetic analysis. Our results showed that RhMLO3 and RhMLO4 had a different expression pattern compared with the other two $M L O$ genes. For example, their transcript levels were downregulated by both biotic and abiotic stresses, and the levels decreased to less than 2-fold in leaves inoculated with $P$. pannosa compared with control leaves. These phenomena were also observed in some Mlo genes from other plants (Chen et al., 2006; Kim and Hwang, 2012; Shen et al., 2012), and some of these genes were shown to play other roles, i.e., as negative regulators of abscisic acid signaling (Lim and Lee, 2014). In addition to their corresponding proteins having a different sequence (S-F-S-F) in the cytoplasmic C-terminus (Kaufmann et al., 2012), the two candidate genes $\mathrm{RhMLO3}$ and $\mathrm{RhMLO} 4$ were not obviously transcriptionally regulated by $P$. pannosa at early time points after infection, so they are not likely involved in susceptibility to powdery mildew. However, they were significantly transcriptionally down-regulated after abiotic stimuli, indicating that they may have other functions.

Our present work demonstrated that $R h M L O 1$ and $R h M L O 2$ may play important roles in the interactions between rose and $P$. pannosa. The discovery of these two genes may provide useful information for the study of mechanisms of powdery mildew susceptibility in rose. We plan to verify the functionality of these genes regarding the mediation of susceptibility to $P$. pannosa using transgenic technology. Recently, Wang et al. (2014) developed hexaploid wheat (Triticum aestivum) plants that exhibited heritable broad-spectrum resistance to wheat powdery mildew (B. graminis f.sp. tritici) by mutation of three Mlo alleles using transcription activator-like effector nuclease (TALEN) technology. We will attempt to generate roses with broadspectrum resistance to $P$. pannosa based on TALEN or other technology in the future.

\section{Literature Cited}

Bai, Y., S. Pavan, Z. Zheng, N.F. Zappel, A. Reinstaedler, and C. Lotti. 2008. Naturally occurring broad-spectrum powdery mildew resistance in a Central American tomato accession is caused by loss of Mlo function. Mol. Plant Microbe Interact. 21:30-39.

Bustin, S.A., V. Benes, J.A. Garson, J. Hellemans, J. Huggett, M. Kubista, R. Mueller, T. Nolan, M.W. Pfaffl, G.L. Shipley, J. Vandesompele, and C.T. Wittwer. 2009. The MIQE guidelines: Minimum information for publication of quantitative real-time PCR experiments. Clin. Chem. 55:611-622.

Chen, Z.Y., H.A. Hartmann, M.J. Wu, E.J. Friedman, J.G. Chen, M. Pulley, P. Schulze-Lefert, R. Panstruga, and A.M. Jones. 2006. Expression analysis of the AtMLO gene family encoding plant-specific seventransmembrane domain proteins. Plant Mol. Biol. 60:583-597.

Cheng, H., W. Kun, D. Liu, Y. Su, and Q. He. 2012. Molecular cloning and expression analysis of Cmmlol in melon. Mol. Biol. Rpt. 39:1903-1907.

Consonni, C., M.E. Humphry, H.A. Hartmann, M. Livaja, J. Durner, and L. Westphal. 2006. Conserved requirement for a plant host cell protein in powdery mildew pathogenesis. Nat. Rev. Genet. 38:716-720.

Derveaux, S., J. Vandesompele, and J. Hellemans. 2010. How to do successful gene expression analysis using real-time PCR. Methods 50:227-230.

Devoto, A., P. Piffanelli, I. Nilsson, E. Wallin, R. Panstruga, and G. Heijne. 1999. Topology, subcellular localization, and sequence diversity of the Mlo family in plants. J. Biol. Chem. 274:34993-35004.

Ding, M. 2012. Establishment of different regeneration system and genetic transformation in Rosa multiflora (in Chinese with English summary). Masters Diss., Huazhong Agr. Univ., Wuhan, China.

Feechan, A., A.M. Jermakow, L. Torregrosa, R. Panstruga, and I.B. Dry. 2008. Identification of grapevine $M L O$ gene candidates involved in susceptibility to powdery mildew. Funct. Plant Biol. 35:1255-1266.

Flor, H.H. 1971. Current status of the gene-for-gene concept. Annu. Rev. Phytopathol. 9:275-276.

Hellemans, J., G. Mortier, A. Paepe, F. Speleman, and J. Vandesompele. 2007. qBase relative quantification framework and software for management and automated analysis of real-time quantitative PCR data. Genome Biol. 8(2):R19.

Humphry, M., A. Reinstaedler, S. Ivanov, T. Bisseling, and R. Panstruga. 2011. Durable broad-spectrum powdery mildew resistance in pea er1 plants is conferred by natural loss-of-function mutations in PSMLO1. Mol. Plant Pathol. 12:866-878.

Jiwan, D., E.H. Roalson, D. Main, and A. Dhingra. 2013. Antisense expression of peach mildew resistance locus O (PpMlol) gene confers cross-species resistance to powdery mildew in Fragaria $\times$ ananassa. Transgenic Res. 22:1119-1131.

Jorgensen, J.H. 1992. Discovery, characterization and exploitation of MLO powdery mildew resistance in barley. Euphytica 63:141-152. Joseph, K., J. Karuppiah, and J.K. Burns. 2010. Expression of ethylene biosynthesis and signaling genes during differential abscission responses of sweet orange leaves and mature fruit. J. Amer. Soc. Hort. Sci. 135:456-464.

Kaufmann, H., X.Q. Qiu, J. Wehmeyer, and T. Debener. 2012. Isolation, molecular characterization, and mapping of four rose MLO orthologs. Front. Plant Sci. 3:244. 
Kim, D.S. and B.K. Hwang. 2012. The pepper MLO gene, CaMLO2, is involved in the susceptibility cell-death response and bacterial and oomycete proliferation. Plant J. 72:843-855.

Kim, M.C., S.H. Lee, J.K. Kim, H.J. Chun, M.S. Choi, and W.S. Chung. 2002. Mlo, a modulator of plant defense and cell death, is a novel calmodulin-binding protein. Isolation and characterization of a rice Mlo homologue. J. Biol. Chem. 277:19304-19314.

Klie, M. and T. Debener. 2011. Identification of superior reference genes for data normalization of expression studies via quantitative PCR in hybrid roses (Rosa hybrida). BMC Res. Notes 4:518.

Leus, L., A. Dewitte, J. van Huylenbroeck, N. Vanhoutte, E. van Bockstaele, and M. Höfte. 2006. Podosphaera pannosa on Rosa and Prunus spp.: Characterization of pathotypes by differential plant reactions and ITS sequences. J. Phytopathol. 154:23-28.

Lim, C.W. and S.C. Lee. 2014. Functional roles of the pepper MLO protein gene, CaMLO2, in abscisic acid signaling and drought sensitivity. Plant Mol. Biol. 85:1-10.

Linde, M. and T. Debener. 2003. Isolation and identification of eight races of powdery mildew of roses (Podosphaera pannosa) (Wallr.: Fr.) de Bary and the genetic analysis of the resistance gene Rppl. Theor. Appl. Genet. 107:256-262.

Linde, M. and N. Shishkoff. 2003. Powdery mildew, p. 158-165. In: A. Roberts, T. Debener, and S. Gudin (eds.). Encyclopedia of rose sciences. Elsevier Science, Oxford, UK.

Liu, Q. and H. Zhu. 2008. Molecular evolution of the $M L O$ gene family in Oryza sativa and their functional divergence. Gene 409:1-10.

Mutui, T.M., H. Mibus, and M. Serek. 2005. Effects of thidiazuron, ethylene, abscisic acid and dark storage on leaf yellowing and rooting of pelargonium cuttings. J. Hort. Sci. Biotechnol. 80:543-550.

National Center for Biotechnology Information. 2014. A tool for finding specific primers. 1 June 2014. <http://www.ncbi.nlm.nih. gov/tools/primer-blast/index.cgi?LINK_LOC=BlastHome $>$.

Pavan, S., A. Schiavulli, M. Appiano, A.R. Marcotrigiano, F. Cillo, and R.G.F. Visser. 2011. Pea powdery mildew erl resistance is associated to loss-of-function mutations at a $M L O$ homologous locus. Theor. Appl. Genet. 123:1425-1431.
Pfaffl, M.W. 2001. A new mathematical model for relative quantification in real-time RT-PCR. Nucleic Acids Res. 29:2002-2007.

Piffanelli, P., F. Zhou, C. Casais, J. Orme, B. Jarosch, U. Schaffrath, N.C. Collins, R. Panstruga, and P. Schulze-Lefert. 2002. The barley MLO modulator of defense and cell death is responsive to biotic and abiotic stress stimuli. Plant Physiol. 129:1076-1085.

Qiu, X.Q., H.Y. Jian, Q.G. Wang, N.N. Zhou, M. Chen, H. Zhang, and K.X. Tang. 2015. Powdery mildew resistance identification of wild Rosa germplasms. Acta Hort. 1064:329-335.

Shen, Q., J. Zhao, C. Du, Y. Xiang, J. Cao, and X. Qin. 2012. Genomescale identification of MLO domain-containing genes in soybean. Genes Genet. Syst. 87(2):89-98.

Tang, K.X. 2009. Study on germplasm resources of Rosa L. in Yunnan (in Chinese with English summary). Ph.D. Diss., Yunnan Univ., Kunming, China.

Vandesompele, J., K.D. Preter, F. Pattyn, B. Poppe, N.V. Roy, A.D. Paepe, and F. Speleman. 2002. Accurate normalization of real-time quantitative RT-PCR data by geometric averaging of multiple internal control genes. Genome Biol. 3(7):research0034. $1-0034.11$.

Wang, Y., X. Cheng, Q. Shan, Y. Zhang, J. Liu, C. Gao, and J.L. Qiu. 2014. Simultaneous editing of three homoeoalleles in hexaploid bread wheat confers heritable resistance to powdery mildew. Nat. Biotechnol. 32:947-951.

Yan, Z.F., O. Dolstra, T.W. Prins, P. Stam, and P.B. Visser. 2006. Assessment of partial resistance to powdery mildew (Podosphaera pannosa) in a tetraploid rose population using a spore-suspension inoculation method. Eur. J. Plant Pathol. 114:301-308.

Yu, L., J.S. Niu, P.D. Chen, Z.Q. Ma, and D.J. Liu. 2005. Cloning, physical mapping and expression analysis of a wheat Mlo-like gene. J. Integr. Plant Biol. 47:214-222.

Zheng, Z., T. Nonomura, M. Appiano, S. Pavan, Y. Matsuda, H. Toyoda, A.A. Wolters, R.G.F. Visser, and Y.L. Bai. 2013. Loss of function in Mlo orthologs reduces susceptibility of pepper and tomato to powdery mildew disease caused by Leveillula taurica. PLoS One 8(7):e70723. 
A

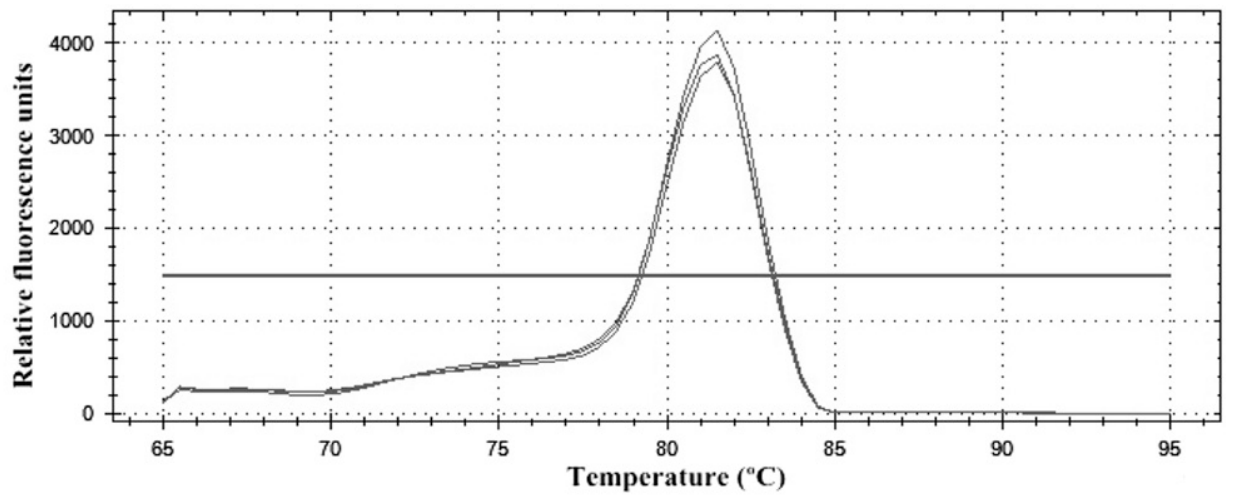

B

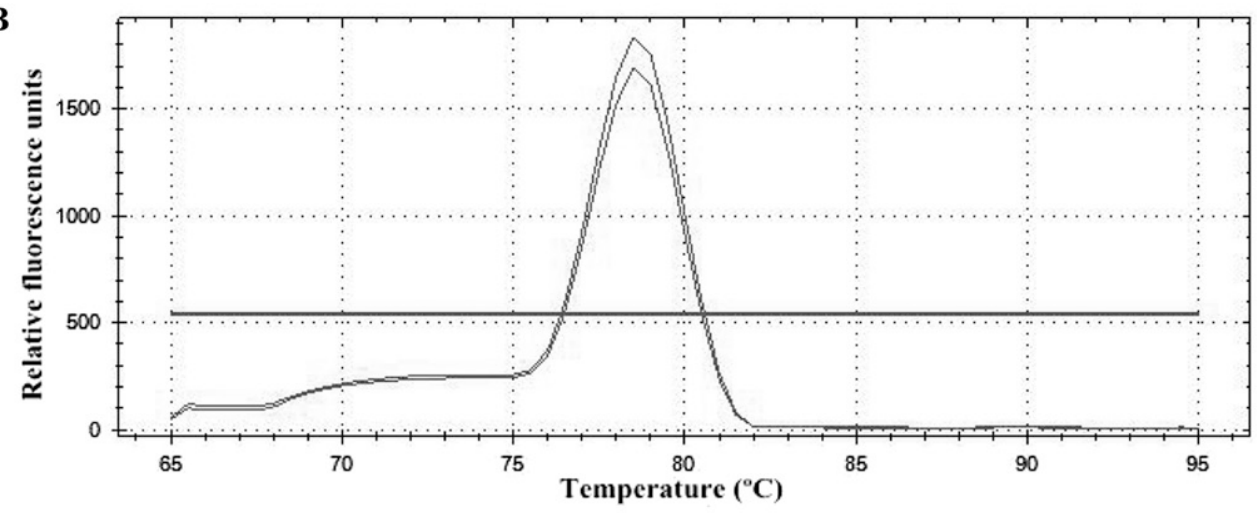

C
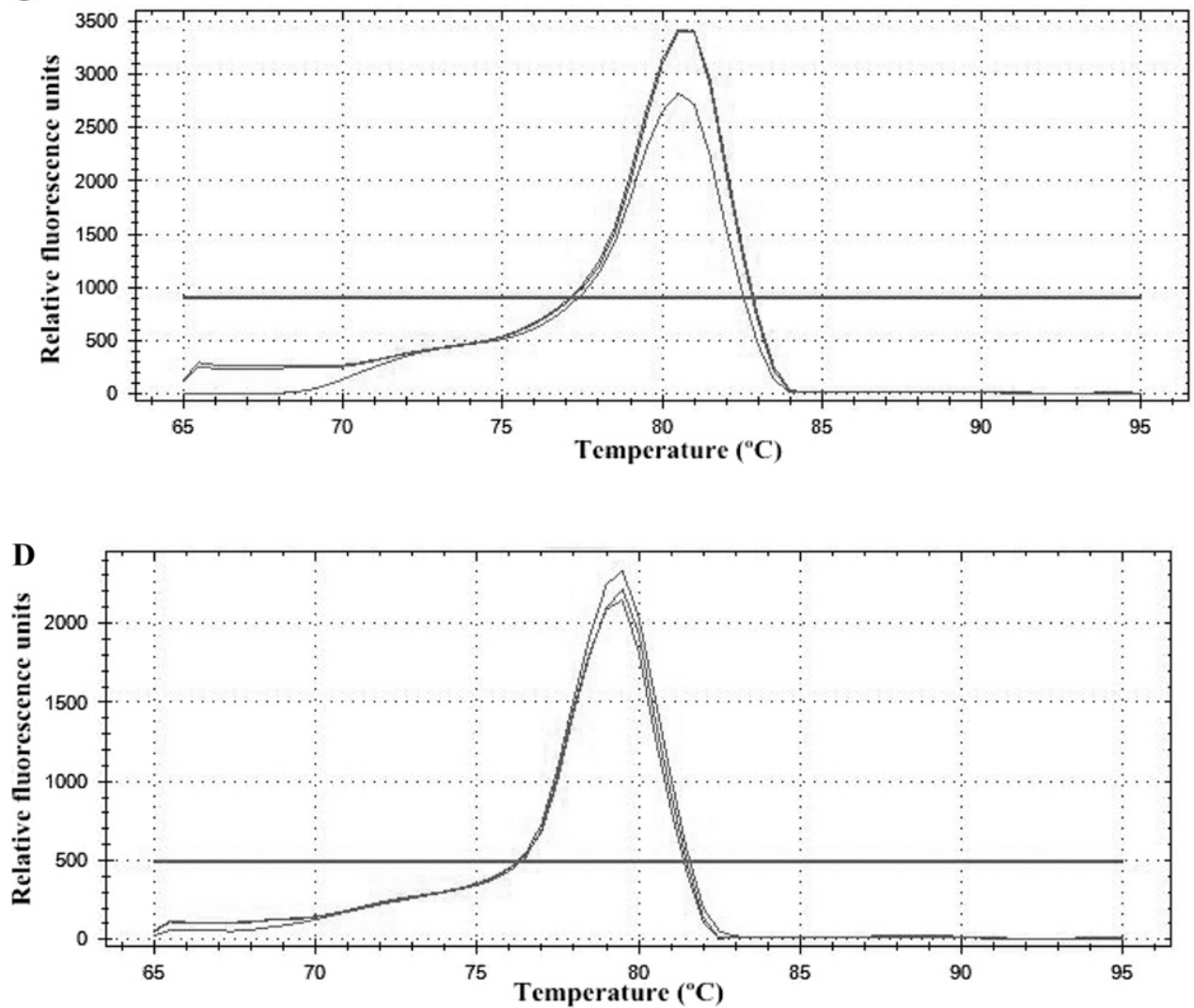

Supplemental Fig. 1. Amplicon specificity for each primer pair \{Rosa hybrida mildew resistance locus o-1 to -4 [RhMLO1-RhMLO4 (A-D)], protein phosphatase $2 \mathrm{~A}[P P 2 A(\mathbf{E})]$, SAND-family protein $[\operatorname{SAND}(\mathbf{F})]$, and ubiquitin-conjugating protein $[U B C(\mathbf{G})]\}$ was tested by a melting curve analysis ranging from 65 to $95^{\circ} \mathrm{C}$ with temperature steps of $0.5^{\circ} \mathrm{C}$ (CFX Manager ${ }^{\top M}$; Bio-Rad, Hercules, CA). 

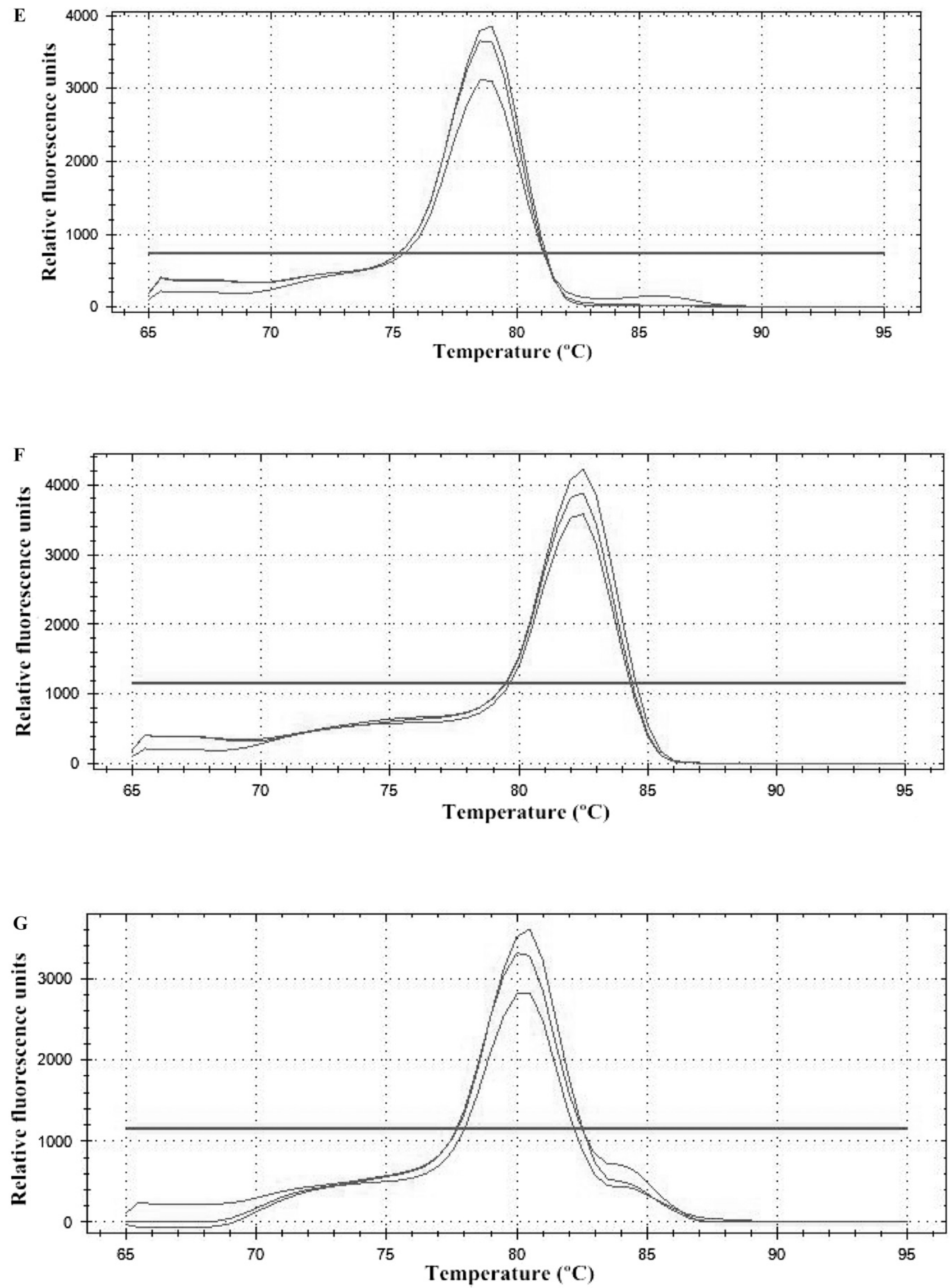

Supplemental Fig. 1. Continued. 
A
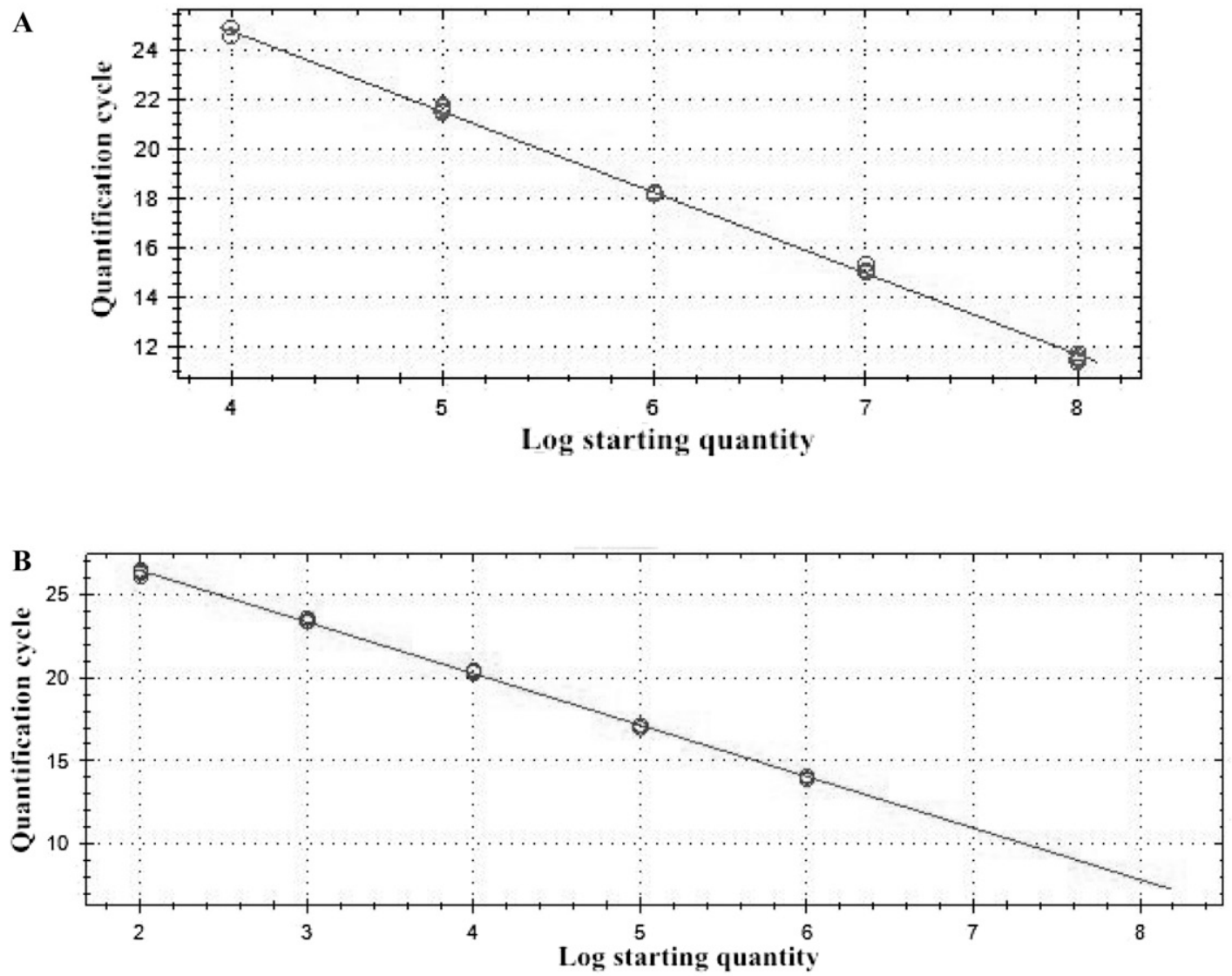

C

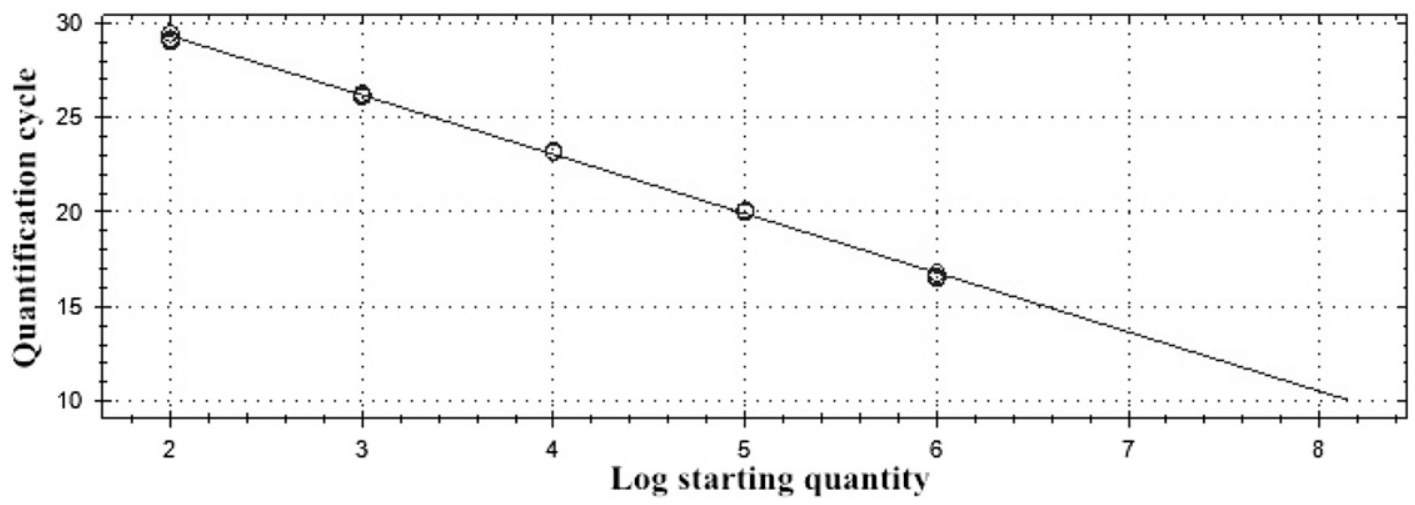

D

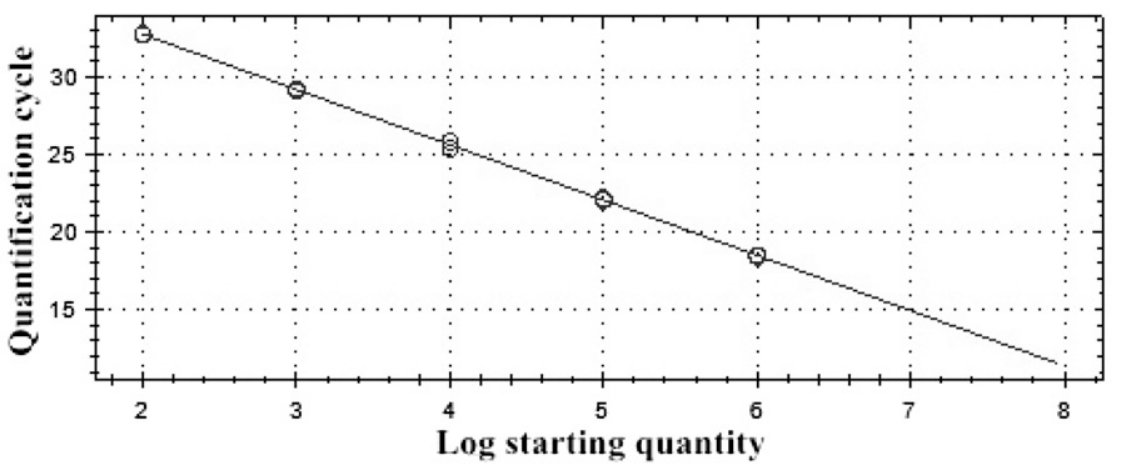

Supplemental Fig. 2. Amplicon efficiency of each primer pair \{Rosa hybrida mildew resistance locus o-1 to -4 [RhMLO1-RhMLO4 (A-D)], protein phosphatase 2A $[P P 2 A(\mathbf{E})]$, SAND-family protein $[\operatorname{SAND}(\mathbf{F})]$, and ubiquitin-conjugating protein $[U B C(\mathbf{G})]\}$ was established using a standard curve (CFX Manager ${ }^{\mathrm{TM}}$; Bio-Rad, Hercules, CA).

J. Amer. Soc. Hort. ScI. 140(4):1-4. 2015. 
E

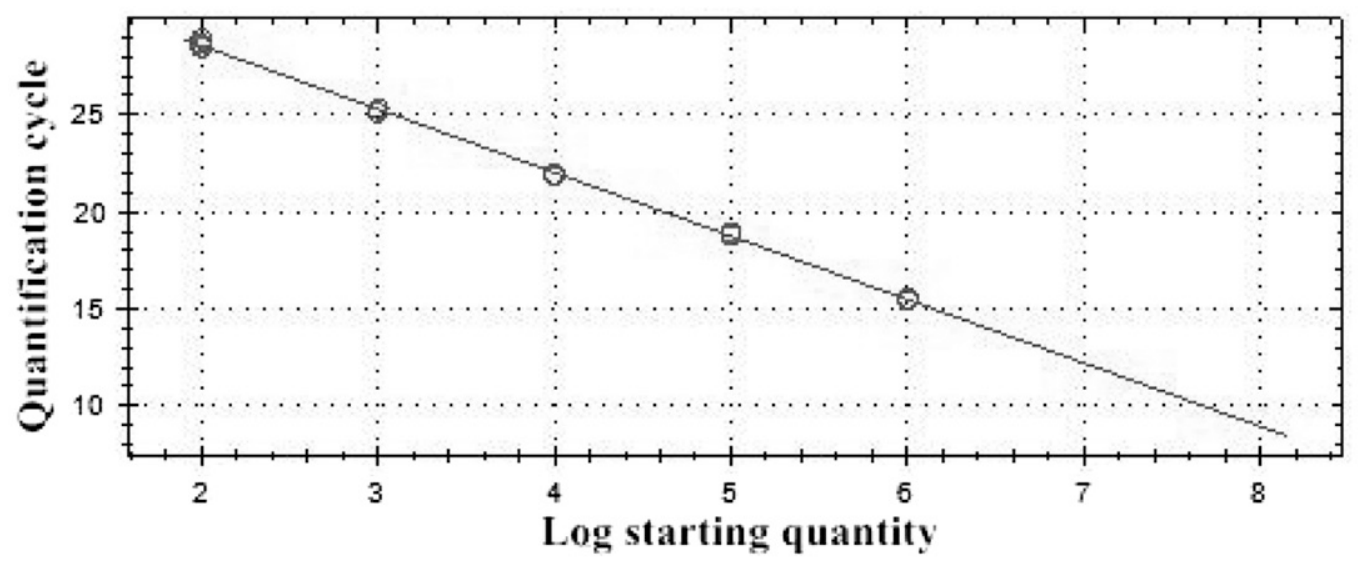

F

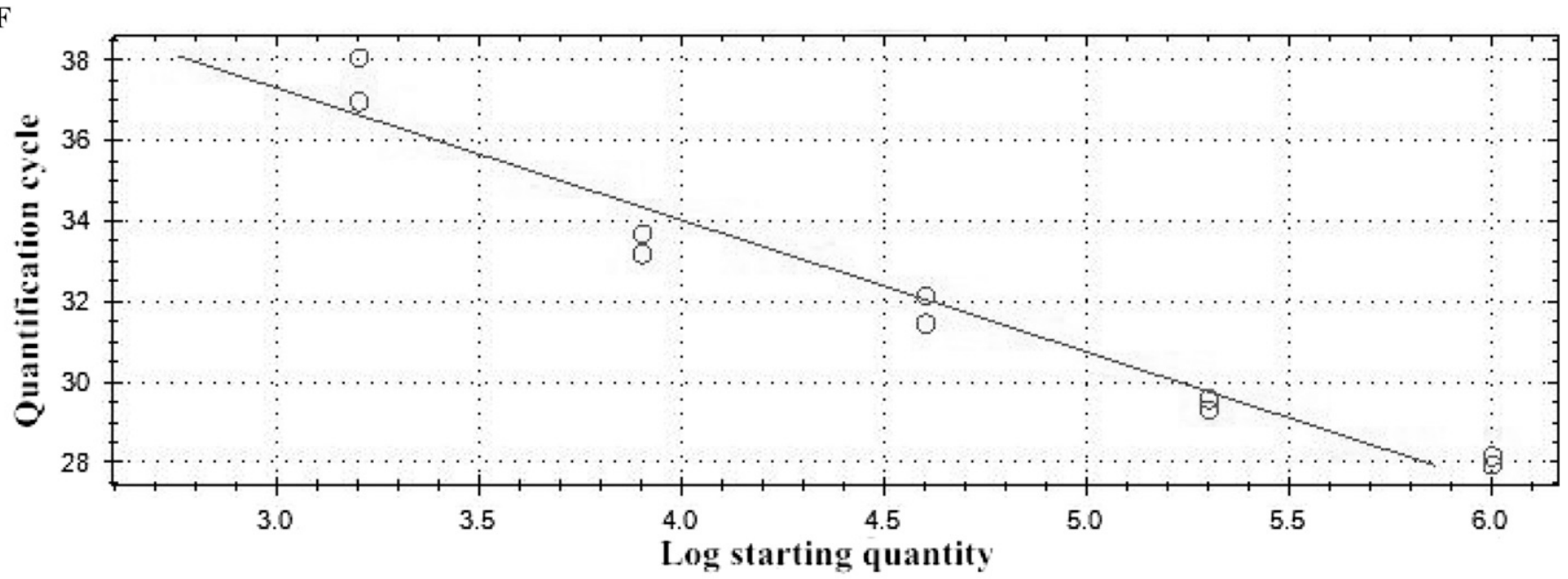

G

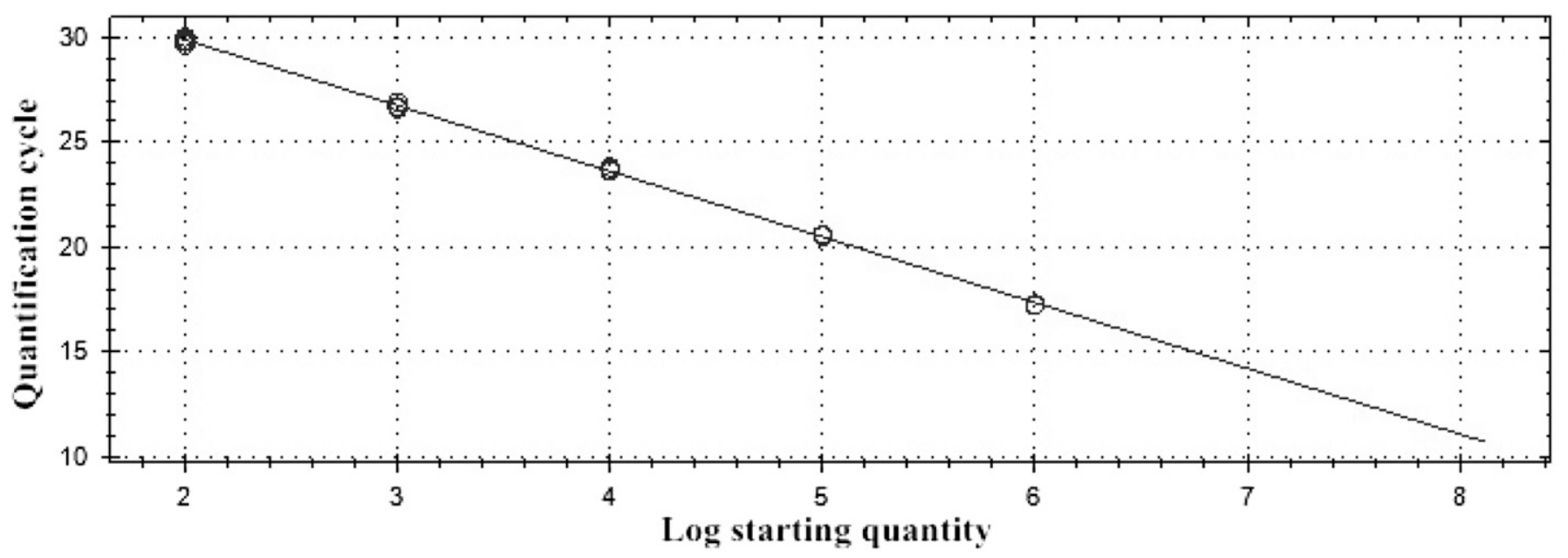

Supplemental Fig. 2. Continued. 